1995-4

\title{
Premarital sexual coercion: Treatment issues for family therapists
}

Kyle D. Killian

Syracuse University

Dean M. Busby

Brigham Young University - Provo, dean_busby@byu.edu

Follow this and additional works at: https://scholarsarchive.byu.edu/facpub

Part of the Other Social and Behavioral Sciences Commons

\section{Original Publication Citation}

Killian, K., \& Busby, D. M. (1995). Premarital sexual coercion: Treatment issues for family therapists. Journal of Marital and Family Therapy, 21, 167-182.

\section{BYU ScholarsArchive Citation}

Killian, Kyle D. and Busby, Dean M., "Premarital sexual coercion: Treatment issues for family therapists" (1995). Faculty Publications. 4590.

https://scholarsarchive.byu.edu/facpub/4590

This Peer-Reviewed Article is brought to you for free and open access by BYU ScholarsArchive. It has been accepted for inclusion in Faculty Publications by an authorized administrator of BYU ScholarsArchive. For more information, please contact ellen_amatangelo@byu.edu. 


\title{
Premarital sexual coercion: Treatment issues for family therapists
}

\author{
Killian, Kyle D; Busby, Dean M . Journal of Marital and Family Therapy ; Hoboken Vol. 21, Iss. 2, (Apr \\ 1995): 167.
}

¿ProQuest document link

\section{ABSTRACT (ABSTRACT)}

Premarital sexual coercion is defined as nonconsensual sexual activity between two persons who are not married to each other but who are involved in an intimate relationship with one another. Factors and consequences associated with premarital sexual coercion are presented, and three possible clinical scenarios are discussed.

\section{FULL TEXT}

Premarital sexual coercion, as depicted in the preceding example, is a serious problem in our society. Although the popular media have recently acknowledged the frequency and consequences of the problem, their use of the term date rape is misleading to the extent that it suggests to some that a man and a woman, as two consenting adults, experience a simple "misunderstanding" in the midst of an evening of romance (Gibbs, 1991, p. 48). Date rape often refers to forced sexual intercourse in a dating situation, whereas the term premarital sexual coercion includes acts other than intercourse which can occur in contexts other than dating relationships. In premarital sexual coercion, a man may engage in sexual relations with a woman and, despite hearing her protests, later insist that the act was not rape. The woman may not be certain whether or not she has been raped, even though she did no give her consent and was physically forced or psychologically manipulated into having sexual relations with the man. Researchers and helping professionals have uncovered some common, if disturbing, themes of sexual violence in cases of premarital sexual coercion. Themes include the victim's sense of shame and/or rage regarding an event out of one's control, the social restrictions and sense of isolation that are attached to an event considered taboo by one's culture, and the consistent underreporting and typically male-to-female nature of the abusive acts (Leidig, 1981). However, just as the silence is beginning to break with regard to child sexual abuse, incest, marital rape, and stranger rape, premarital sexual coercion has also garnered increased attention in the media and in the field of therapy, especially since the early 1980s.

\section{PREMARITAL SEXUAL COERCION DEFINED}

Premarital sexual coercion is defined as nonconsensual sexual activity between two persons who are not married to each other but who are or have been involved in an intimate relationship. The persons involved could be two people who have been dating, lovers, persons living together, and/or fiancees. The term activity is used to include acts in addition to sexual intercourse, such as fondling, fellatio, and anal intercourse, which are part of the definition of rape in states such as Ohio (Harney \&Muehlenhard, 1991). The term nonconsensual refers to the absence of mutuality in the decision to engage in the sexual act and the imposition of one person's will on another. Although some men do report having had sexual intercourse which they did not want with female partners due to psychological pressure from their partners (Miller \&Marshall, 1987), the greater average size and strength of men and the corresponding dearth of cases in which physical force is applied by females to males has contributed to an emphasis in the literature on male-to-female forms of premarital sexual coercion. Hence, the focus of this paper is female victimization. 
Grauerholz and Koralewski (1991) defined sexual coercion as "the act of being forced, tricked or pressured to engage in a sexual act or acts" (p. ix). Sexual coercion involves the application of physical or psychological intimidation or threat as a way of controlling the victim (Kelly, 1988). Intimidation or threat can be readily identified in its physical forms, such as the use of deadly weapons or beatings by the perpetrator. But more subtle means of force, such as the man's use of his body weight, are not as clearly identified by either victims or the legal system (Estrich, 1987).

Furthermore, the application of psychological pressure or manipulation, such as threatening to end the relationship, is even more difficult to classify as a use of force. Miller and Marshall (1987) found that $17 \%$ of their sample of female undergraduate students reported having unwanted intercourse with a man because they had felt pressured by his continuing arguments, and another $15 \%$ reported having unwanted sexual intercourse because the man became so sexually aroused that they felt it was useless to attempt to stop him. Thus, subsequent to being raped, a woman may struggle to explain to law enforcement, lawyers, or even herself the experience of having felt threatened or endangered when (a) the perpetrator was not a stranger but someone she knew or trusted, and (b) the man refrained from using physical force.

\section{THE SCOPE OF THE PROBLEM}

The accurate estimation of the prevalence of premarital sexual coercion is a difficult task. Obtaining more accurate responses by avoiding the use of terms such as rape and sexual assault, Russell (1984) found that $21 \%$ of the women in his sample had been raped by acquaintances. Koss and Oros (1982) found that about $20 \%$ of the female respondents at Kent State University reported that they had been physically forced to have intercourse on a date. Muehlenhard and Linton (1987) found that $14.7 \%$ of college women had been raped in a dating situation, and the length of time partners had known one another was unrelated to risk of sexual aggression.

Other estimates of the prevalence of rape by acquaintances range from 16\% (Kanin, 1985; Kiernan \&Taylor, 1990) to $27 \%$ of women (Koss, Gidycz, \&Wisniewski, 1987 ; Miller \&Marshall, 1987). Miller and Marshall (1987) found that $15 \%$ of the men in their sample reported having forced sexual intercourse with a woman while in a dating situation at a university. It should be noted that the data from this study lent support to past findings that few acts of coercive sex are officially reported and "most victims and victimizers do not acknowledge coercive sex (or date rape) as a rape experience" (Miller \&Marshall, 1987, p. 46). In light of the phenomenon of underreporting and the range of sexual acts other than sexual intercourse included in our definition, the actual prevalence of premarital sexual coercion is much higher than one fourth of all women.

\section{CONSEQUENCES OF PREMARITAL SEXUAL COERCION}

Consequences for the Victim

The devastating effects of sexual assault can include symptoms of anxiety, depression, and increased incidence of sexual dysfunction (Becker, Skinner, Abel, \&Treacy, 1982; Ellis, Atkeson, \&Calhoun, 1981; Kilpatrick, Veronen, \&Resick, 1979). Koss, Dinero, Seibel, and Cox (1988) found that the postrape psychological symptoms experienced by the victims of stranger and acquaintance rape did not differ; both groups manifested scores on the scales of depression and anxiety that were significantly higher than those of the population of nonvictimized women. Koss et al. (1988) also found that $29 \%$ of the women who had been raped by a stranger and $62 \%$ of the women raped by an acquaintance did not perceive their assault as any kind of crime. Seventy-three percent of the victims of stranger rape told someone about the assault; only $44 \%$ of those victims raped by a steady boyfriend or spouse discussed the experience. The researchers noted that "these levels of confiding, helpseeking, and reporting were painfully low[,] especially in light of the potential therapeutic effect of talking" (p. 21). Davis and Friedman (1985) determined that talking about a traumatic experience is the single most therapeutic behavior in which victims can engage.

According to Koss and Buckhart (1989), a victim's cognitive map of the abusive event has a significant effect on the chronicity of postrape psychological effects. With a basic belief destroyed (e.g., the world is a safe place, people are trustworthy), a victim's capacity for openness and trust in her intimate relationships may be severely curtailed during the recovery process. Barrett (1982) stated, "when the rapist is a friend or date, not only has her 
body been violated, but her trust in another human being betrayed, and her faith in her own judgment has been shaken" (p. 48).

\section{Consequences for the Family}

There may be relatively few readily observable effects on a victim's family of origin if she chooses, like so many victims, not to disclose her experience of sexual coercion. However, clinical experience does suggest that keeping such shameful secrets can form a boundary between the victim and her family members. For example, in keeping the coercion secret, a victim may experience anxiety and discomfort as relevant topics are discussed within her family (e.g., date rape, her relationship with the perpetrator) and as she attempts to camouflage the problem with deception and distorted information (Karpel, 1980). Family members are also likely to experience unexplainable tension as topics related to the coercion are addressed. On the other hand, disclosure of sexual coercion may upset the fragile equilibrium of the family and precipitate a "crisis." White and Rollins (1981) found that a family's degree of distress is largely contingent on the victim's agitation and distress subsequent to the assault. Family members may express emotional responses and symptoms such as anger, revenge, helplessness, and guilt-typical reactions to catastrophic events (Burge, 1983).

\section{Consequences for Society}

Fear of stranger rape restricts the everyday routines and activities of many women. Cues such as the setting of the sun or the prospect of crossing a parking lot alone carry profoundly different meanings for women than for men. But changes in one's personal habits, such as being escorted home at night by a trusted male friend, do not address the frightening issue raised by premarital sexual coercion: that a woman's chances of being raped by someone she knows far outweigh those of being attacked by a stranger lurking in the shadows. How do women protect themselves from someone they do not consider a threat?

Consequences for the Couple Relationship

If $60 \%$ of all victims of acquaintance rape do not perceive their experience of sexual coercion to be a crime of any kind (Koss et al., 1988), how do partners perceive acts of abuse perpetrated by or against themselves? It is possible that premarital partners, in attempts to justify an unacceptable offense, engage in a form of collusion in the guise of romanticism. For both men and women, "being in love" makes courtship qualitatively different from other intimate relationships (Lloyd, 1991). Cale, Henlon, Koval, Christopher, and Lloyd(1982) found that one third of those who experienced violence in a courtship relationship believed that the violence meant love; only $8 \%$ thought it meant hate. Couples may believe that destructive facets of courtship, even violence, will be resolved upon marriage (Henton, Cate, Koval, Lloyd, \&Christopher, 1983). What impact does sexual coercion have on the dynamics of premarital relationships?

Over time, a woman may develop a condition of learned helplessness, which has a devastating impact on selfesteem and may lead a person to take personal responsibility for any negative situations encountered (Abramson, Seligman, \&Teasdale, 1978). This may account for victims' tendency for self-blame. A cycle of abuse could develop, with the victim's self-blame and eroding sense of self-esteem and autonomy diminishing her capacity to challenge her partner's behavior and/or remove herself from the abusive situation. This cycle could lead to an escalation of unchecked coercion which increases in frequency and severity over time. Thus, the therapist can expect to see verbal and nonverbal metaphors for the power imbalance present in couples in which the male sexually abuses the female.

Sexual assault in the context of a loving relationship will usually have devastating effects on the sexual functioning of the couple. Victims may find themselves at one of two extremes, either withdrawing and avoiding any hint of sexual activity, or simply giving in to avoid being abused more severely. It is unrealistic to expect that a woman who has been sexually assaulted will be anything other than guarded with respect to sexual intimacy with the perpetrator. This guardedness may lead to inhibited sexual desire, orgasmic difficulties, or somatic symptoms that interfere with intimacy. Perpetrators are also likely to lose respect for themselves and their partners as they notice the effects of their actions. As a result of the increased distance in the relationship, perpetrators can often come to the erroneous conclusion that they are unlovable and that their partners are involved with someone else. 
When the victim is accused of infidelity, she has had insult added to injury. This cycle of sexual distance, guilt, accusations, and pain can escalate into more instances of sexual coercion and/or the dissolution of the relationship.

\section{THE TREATMENT OF PREMARITAL SEXUAL COERCION}

Many professionals who work with abused women believe the only solution to an abusive relationship is its termination. Rosenbaum and O'Leary (1986) stated, "To this end, the treatment of choice is usually aimed at providing support, legal assistance, vocational counseling and/or training, child care, and advocacy through the social system" (p. 389). However, many women are unable or unwilling to exit their relationships and choose the route of therapy instead. In the Code of Ethics of the American Association for Marriage and Family Therapy, two principles are relevant to clinical cases involving abuse:

Marriage and family therapists respect the right of clients to make decisions and help them to understand the consequences of these decisions. Therapists clearly advise a client that a decision on marital status is the responsibility of the client....Marriage and family therapists continue therapeutic relationships only so long as it is reasonably clear that clients are benefitting from the relationship. (AAMFT, 1991, pp. 1-2).

These principles are useful in drawing out complex issues in treating persons presenting with premarital sexual coercion. The first principle states the importance of therapists' respecting the decision-making capacity of their clients, who are solely responsible for decisions regarding continuing or ending personal relationships. Considered in isolation, the first principle makes a therapist's decision on the issue of conjoint treatment relatively simple. However, the second principle suggests that the therapist has a responsibility to determine whether therapy is benefiting the client. If the therapist is seeing a couple and the safety of the woman is clearly at risk, is couple therapy benefiting the client? In the instances when the therapist believes that sexual coercion is likely to occur and both partners want to continue couple therapy to the exclusion of other treatment modalities, it may be necessary to refer the couple elsewhere. Still, a conflict between the therapist's perspective and the client's perspective can usually be avoided if the client is provided adequate space to explore the positive and negative consequences of continuing the relationship without being pushed or dictated to by the therapist. Since it is often not possible to discuss such issues in a couple context, the therapist must provide individual sessions so that the client can safely discuss all the ramifications of remaining in a relationship in which she has been coerced. The assessment process for clients presenting with premarital sexual coercion is intended to follow the spirit of these ethical principles and to ensure the safety of all persons involved.

Assessment of Premarital Sexual Coercion

An essential factor affecting the therapist's approach to treating any presenting problem is the number and identity of the presenting clients. In actual practice, some of the dilemmas inherent in treating persons presenting with sexual coercion are simplified by the decisions already made by the clients. For example, many victims of premarital sexual coercion have decided to discontinue contact with the perpetrator. Hence, no ethical dilemma exists. However, there are at least two other case scenarios which are not so simple.

Victim presents for individual therapy. While still involved with the perpetrator, the victim may present for treatment as an individual. The client may be seeking help around issues of empowerment and may require crisis intervention, and, although couple therapy is not appropriate at this time, it may be sought later. Therapists first must assess the client's safety. A decision tree is presented in Figure 1 to guide the careful assessment and treatment of premarital couples who may be experiencing the problem of sexual coercion. If she is suffering from a recent abusive incident and feels that her safety has been threatened, the therapist should provide crisis intervention.

According to the ethical principles previously discussed, the responsibility for choosing to maintain the couple relationship rests with the victim. Unfortunately, in regard to the issue of safety, the quality of the relationship is determined by the perpetrator's actions, attitudes, and history. Most of the energy in treatment is directed toward empowering the victim so that she can see herself as a survivor with choices.

Couple presents for conjoint therapy. The most complex case scenario occurs when a couple presents with issues 
other than premarital sexual coercion, but the coercion emerges over the course of therapy. Partners may complain about communication problems, or other issues, and therapy proceeds with its ups and downs until something is said which hints at the possibility of sexual coercion. Therapists should be aware of common signs of an abusive relationship (see Koss et al., 1988; Rosenbaum \&O'Leary, 1986).

Once there is any indication that sexual coercion has occurred in the couple's relationship, it is essential for the therapist to provide the female partner the opportunity to communicate her inner thoughts and feelings concerning the relationship. Individual sessions within the context of couple therapy provide a safe and private space for women to express fears and concerns without threat of reprisal from their male partner. The frequency and severity of the coercion should be discussed with the female client, and the gravity of any abusive incident should be clarified. The possibility of the coercion happening again must be clearly communicated to the client. Again, victims must be provided adequate time, space, safety, and support to begin to perceive themselves as survivors, people who can make choices which enhance their lives.

When one or both partners do not wish to remain together (i.e., there is substantial doubt regarding the viability of the relationship), referral to a support group and/or individual or group counseling should be considered (see Figure 1) (Rosenbaum \&O'Leary, 1986, p. 389). (Figure 1 omitted) Beavers (1985) stated, "if each partner can openly state that $s /$ he wants to see if they can live together happily, there is a solid basis for treatment" (p. 159). Upon completion of assessment, the therapist may elect to provide the couple conjoint therapy if and only if (a) the partners have stated their mutual willingness to work, and (b) the therapist believes sufficient safety exists so that the victim of the abuse is in no immediate danger. For the second criterion to be fulfilled, the sexually abusive partner must be willing to contract for no violence. The male partner's willingness to commit to a no violence/coercion contract is necessary before the couple can be seen conjointly by the therapist. Willbach (1989) asserted the great importance of a binding nonviolent contract:

If the violent family member will not or cannot agree to stop the use of violence in all circumstances, or exhibits by his actions that he cannot live up to the agreement, then...couples therapy is not the appropriate modality: It will not be as effective in changing behavior as individual and/or group therapy and has negative consequences From an ethical viewpoint. (p. 48)

Once these criteria have been fulfilled, the therapist can proceed with conjoint treatment.

Therapeutic assessment: Detecting premarital sexual coercion. The first step in treating sexually coercive men and the recipients of their coercion is, of course, identification of those requiring services. Therapists may not become aware of clients' experiences of sexual coercion in their relationships as part of the typical intake and assessment process for several reasons. First, clients may be in denial due to either romantic beliefs or failure to recognize sexual coercion as abuse. Second, a female client may anticipate a reprisal from her partner following disclosure of sexual coercion, whether it is in the form of further violence of a physical or sexual nature, withdrawal of affection, or threats to end their relationship. It is important for therapists to acknowledge these factors which may influence clients' willingness to disclose premarital sexual coercion.

Symptoms of abuse and trauma of all types include high anxiety, depression, intense shame and guilt, and sexual problems (Koss et al., 1988). Low self-esteem in either partner may be an indication of violence or potential violence. In addition, alcohol use is associated with all forms of family violence (Rosenbaum \&O'Leary, 1986). A common characteristic of physically and sexually coercive men is extreme jealousy, which is frequently manifested in attempts to isolate the woman socially. Muehlenhard and Linton (1987) found that sexually aggressive males believed rape myths significantly more than both women and other males.

Assessment instruments are helpful in that they can obtain information in a few minutes while a therapist might require much more time to obtain the same amount of data through an interview (Stahmann \&Hiebert, 1987). The premarital couple's strengths, weaknesses, and degree of readiness for marriage may be measured through PREPARE (Olson, Fournier, \&Druckman, 1986), the Caring Relationship Inventory (Shostrum, 1975), and PREParation for Marriage (PREPM) (Holman, Busby, \&Larson, 1989). In addition to providing scores of couple readiness for marriage, the PREPM provides measures of partners' self-esteem, emotional health, openness and 
self-disclosure, and use of addictive substances. Regarding the detection of family history of abuse, the PREPM also includes items which inquire how frequently acts of physical and sexual violence occurred in clients' families of origin, as well as in their current relationships. Additional instruments that may be helpful include the Brief Symptom Inventory (BSI) (Derogatis, 1975), the Marital Satisfaction Inventory (Snyder, 1985), the Sexual Experience Survey (Koss \&Oros, 1982), and the rape myth scale (Burt, 1980).

Individual Treatment of Premarital Sexual Coercion

Crisis intervention with victims. Brown and Ziefert (1988) cited research (Bowker, 1983; Hanneke \&Shields, 1985) which has documented the efficacy of crisis intervention for helping survivors of various forms of sexual assault deal with their feelings and reestablish coping capacities. This stage of intervention often involves assisting women in reexamining their beliefs about sexual assault and helping them to stop blaming themselves for the abuse. The therapist can challenge clients' subscriptions to prevalent rape myths and facilitate differentiation between feelings of fear, terror, and revulsion associated with the sexual coercion and feelings of guilt and shame associated with an act for which they clearly were not responsible.

Women's support groups may be the next step in treatment since "group settings provide an opportunity to decrease women's sense of isolation and powerlessness and are a vehicle to enhance competence" (Brown \&Ziefert, 1988, p. 98). Although these treatment modalities function to give women permission to talk about their traumatic experiences and reconnect them to a supportive and empowering community, Brown and Ziefert (1988) conceded that "it is not enough to offer crisis intervention and self-help groups" to victims of sexual violence. Once crisis intervention has been provided, victims of sexual coercion should be referred for individual or group therapy (e.g., individual psychotherapy, Women for Women support group).

Treatment guidelines for victims. The therapist's role is to help the survivor gain sufficient confidence and understanding to make decisions that promote her safety and satisfaction in the long term. In order to help survivors improve the quality of their lives, therapists must (a) help them place responsibility for the sexual coercion on the perpetrator, (b) clarify the seriousness of the coercion by investigating its frequency and severity and assessing the dangerousness of the perpetrator, and (c) help survivors understand that there are no guarantees that the perpetrator will not resort to sexual violence again. Therapy must not be seen as a guarantee that coercion will never reoccur.

Treatment for perpetrators, For male clients with a history of sexually abusive behavior, individual therapy is complicated by client denial, a frequently violent developmental history, and the repetitive, cyclical nature of abusive behaviors. Wolf(1988) asserted that early experiences act as "potentiators" through their influence on later attitudes and behaviors. Over time, sexually aggressive behavior can become ingrained in the perpetrator's personality structure and become a recurring, chronic problem. Because of perpetrators' denial or wish to conceal the full extent of their sexually aggressive behaviors, a comprehensive assessment should include "a review of all data available including victim statements, witness statements, and attendant assessments...by their therapist or by family members" (Wolf, 1988, p. 145).

Once an historical perspective on the perpetrator's problem has been procured, the therapist can begin to treat the specific patterns associated with the sexual aggression. Wolf (1988) recommended that therapists facilitate the perpetrator's recognition of distortions in his beliefs and attitudes which have worked to create and maintain sexually coercive behaviors. Therapists also need to guide the client back to childhood experiences which contributed to the development of current attitudes and beliefs which continue to justify abusive acts. Wolf (1988) also suggested the use of a combination of "confrontive group therapy, 'traditional' insight talk therapy, family therapy, couples therapy, and cognitive behavioral counterconditioning" (p. 146). Although still experimental, Wolf's approach has shown itself to be very effective.

Conjoint Treatment of Premarital Sexual Coercion

An important issue to address in the treatment of premarital couples who have experienced sexual coercion is how they differ from marital couples struggling with the same problem. Premarital couples sometimes experience more ambiguity, romanticism, and denial than married couples. 
The "good times" are often perceived as better in premarital relationships than in marriage because partners are spending more time with one another and are participating in more rewarding experiences (Beck, 1988; Stahmann \&Hiebert, 1987). Premarital couples frequently have fewer stressors with which to cope, such as parenting responsibilities or financial strain from house payments and other joint ventures. As a result, they may have more emotional energy available for one another. Many premarital couples may be experiencing a strong, positive attachment with a partner for the first time and may be quite impressionable. Partners may make statements such as "We have so much in common" or "This is the first time I have found someone I can really talk to."

Rewarding experiences work to diminish the impact of abusive incidents and couples may view the violence as an aberration rather than an important pattern in the relationship. This dynamic is complex, with premarital partners believing they can readily choose to end the relationship because they are not married. At the same time, rewarding behaviors contribute to the emotional bond between partners, and the guilt connected to the coercion creates isolation and impedes their ability to sort out their feelings. This situation makes reality testing particularly difficult for the clients and the therapist.

The rewarding aspects of the premarital relationship and the lower level of commitment can create profound ambivalence in victims of premarital sexual coercion, especially those suffering from low self-esteem. If they had to choose between a rapist and a loving partner, the decision would be simple; unfortunately, the victim has experienced both persons in her partner. Because of the cognitive dissonance associated with attempts to reconcile these two extreme positions, victims often ignore the rapist and focus on the loving partner. With time, the struggle between these two extremes can lead to paralysis and lower levels of self-respect. Victims ask themselves "Why can't I make up my mind about him?" In turn, the efforts exerted to maintain the facade of a happy relationship drain energy from the victim and can lead to depression. This spiral can lead to self-destructive choices such as unplanned pregnancy, alcoholism, or drug use. Perhaps the most intensely ambiguous scenario is the one in which the perpetrator does not coerce his partner again during the courtship. Further coercion from the male might push the victim beyond paralysis and facilitate her choice to end the relationship.

The perpetrator can experience a similar spiral if his attempts to rationalize, justify, or deny his behavior are not successful. He may struggle to maintain his self-respect knowing he has coerced and frightened his partner. Each time he experiences loving feelings for her he is reminded of what he has done, leading to an experience of love and self-hate. He feels guilty, and, as his frustration and anger increase, his resources for controlling abusive behavior may decrease. He too may resort to self-medication to escape his feelings. For both victims and perpetrators, marriage can be seen as a welcome relief because it temporarily ends the dilemma of whether to stay in or get out of a relationship so confusing in its mixture of love and hate.

Therapists can enter the system at a variety of points in this pattern. One of the most common places to enter is right before the wedding as the couple requests help in "just ironing out a few minor issues." The following case example represents a sample of some of the complicated dynamics that can emerge when treating premarital couples in which the woman has been sexually coerced.

Case example. A couple who had been dating exclusively for a year and a half presented for premarital counseling at a university clinic. The man (Dan) was a 24-year-old salesman and the woman (Shari) was a 20-year-old secretary. Their presenting problems included frequent arguments and the stress the couple had been experiencing as their wedding approached. After careful perusal of the questionnaires completed by the couple, the therapist noticed that the female client had high scores on questions relating to anxiety and fear. The therapist decided to explore the content of her fears in more detail.

During the initial couple session the therapist asked specific questions about Shari's fears and anxiety. Shari responded with vague comments about stress at work and sometimes worrying about making Dan angry. Each time the therapist inquired about her fears in this relationship, Shari shut down and looked to Dan to speak for her. As the couple session progressed, the therapist continued to feel uncomfortable with Shari's responses and asked them to come for some individual sessions the next time so that they could focus on their families of origin. The following week, the therapist met with each of the partners, discussing their family backgrounds and exploring 
Shari's fears in more depth. In individual sessions, both partners disclosed that they had witnessed acts of physical violence in their families of origin. In her session, Shari also disclosed that sometimes Dan came home drunk and wanted to have sex. She said that he was frightening when he had been drinking and did not listen to her when she told him to leave her alone.

Upon disclosure of premarital sexual coercion, the therapist had several tasks to attend to, including the provision of adequate time, space, and support to help the victim make a decision regarding the future of the relationship. The therapist emphasized the gravity of the coercion, the strong possibility that such abuse could occur again, and the implications for Shari if she continued to experience coercion. The therapist informed her of the various services available (e.g., local women's shelters) should she feel endangered again by Dan. Facilitated by the therapist, Shari formulated a plan of action in the event of another crisis, including a safe place to go and a list of resources for help.

Once a safety plan was established, the therapist proceeded to discuss individually with Dan his perceptions of his drinking and the sexual coercion as it had been presented by Shari. Dan demonstrated belief in several rape myths, including the notion that women refuse men's advances even when they desire intercourse (i.e., "she says 'no' when she really means 'yes'"). Dan also expressed confusion regarding some of the events Shari had referred to, conceding that his memory of those events was vague. The therapist pointed out that it was likely that not only his memory was impaired when he became intoxicated, but also his judgment and ability to assess accurately his partner's real wishes and comfort level with his sexual advances.

Dan said he had to think about this, but he had been aware that lately Shari had shown little or no interest in making love even when he had not been drinking. He admitted that he might have forced himself on his partner and that that was something of which he was ashamed. Following Dan's concession that he might have perpetrated premarital sexual coercion, the therapist obtained a no violence/coercion contract from Dan. The therapist indicated that Dan's habit of "winning" in the short term through coercion and intimidation made him lose in the long term and repeatedly emphasized that physical and sexual violence were unacceptable under any circumstances. In addition, the therapist instructed Dan to begin monitoring his drinking by counting the number of drinks he consumed per day.

After this session, the couple missed two consecutive appointments. It is common for perpetrators to avoid therapy following confrontation by the therapist. This is more likely to occur if the therapist does not strike a balance between supportive and confrontive behaviors and/or the perpetrator is extremely defensive.

Several weeks later, Shari contacted the therapist and asked for another individual session. Over the next several months the therapist saw Shari for individual work around empowerment, anxiety, and her family-of-origin issues. As Shari made some progress, she started to consider changing her career and enrolling in college. Shari's movement in therapy was associated with a decrease in her tolerance of Dan's manipulation. This resulted in two episodes of her refusing to engage in intercourse upon Dan's demand and leaving the house after Dan threatened to leave her.

After a month more of individual sessions, Shari requested a return to couple therapy, wanting to give the relationship one more chance. The therapist helped her recognize that Dan might coerce her again and that he might continue to use alcohol for years. Even with these risks Shari felt that "Dan was worth it." Dan came in, although somewhat reluctantly. To facilitate Dan's empathy and understanding of Shari's experience of being coerced, the therapist guided him back to an incident in his childhood in which he himself was controlled, manipulated, and humiliated and helped him explore the feelings associated with that event. Dan was able to relate several frightening episodes when his father had beaten him. The therapist was able to encourage him to express the fear he had had as a little child and the pain of never getting "close to Dad." Several times during the next few sessions, when Dan would express a clear emotion, the therapist would ask questions to get Dan to recognize that Shari was having similar feelings toward him. Enhancing the male partner's empathy in this way over several individual sessions decreased Dan's perception of sexual coercion as a valid option in his behavioral repertoire. At the same time, the therapist was careful not to collude with Dan by buying into his denial or rationalizations 
(e.g., "I was abused as a child," "I'm an alcoholic," "She was provoking me"). Although therapists may empathize with a client's history of past abuse or neglect in his family of origin, the focus must remain on accountability. "Being accountable means living up to expectations, taking responsibility for one's own behavior, and acting one's age [acting like an adult]" (Combrinck-Graham, 1991, p. 201).

From this point, therapy consisted of individual work with Dan and Shari along with monthly couple sessions. The therapist reiterated that any violation of the contract for no violence or coercion would result in termination of conjoint treatment. The therapist approached conjoint treatment of the premarital couple with caution. The nature of courtship, with the man traditionally possessing a disproportionate amount of control and the woman exhibiting considerable dependence (Lloyd, 1991), makes intervention into premarital relationships especially difficult. For example, having been socialized to be responsible for events and behaviors occurring in relationships, Shari believed that the coercion was somehow her fault, a belief which meshed well with Dan's tendency to underestimate or minimize the impact of his own behaviors.

Although Dan's subjective reality had been that he was helpless and "out of control" during incidents of sexual coercion, the therapist made it clear that violence was still a choice. This was accomplished largely in couple sessions by helping the couple describe experiences when Dan had elected not to become violent and exploring the specific strategies Dan had used successfully to avoid outbursts. These exceptions not only provided him with a sense of hope but also sent the underlying message that when he failed to use these strategies he was choosing to be violent.

In seeing the partners in the context of their relationship, the therapist was able to access their individual issues and see how key relationships in each partner's family of origin were being recreated (Napier, 1987). For instance, the role of the frustrated, controlling father was a part of both Dan's and Shari's family scripts, and both partners while growing up had observed violent altercations between their parents. As these old scripts were explored, the couple was taught to recognize the impact of the scripts on their expectations, interactions, and the regulation of distance in their relationship.

The therapist confronted and challenged rape-supportive beliefs held by both partners (e.g., that a woman needs to be persuaded or convinced to have sex, that a woman says "no" but means "yes," that a male can be a "real" man only by "scoring"). In addition, the therapist addressed "the romantic veneer through which premarital behavior was viewed by both partners" (Lloyd, 1991, p. 18). One belief held by this couple was that with marriage and children they would no longer fight or have problems. The therapist helped them face the reality of married life with its stressors and challenges by having the clients interview several of their friends who were already married and ask these friends specific questions. Each of these experiences helped the couple realize that, if anything, marriage exacerbated existing problems.

Another goal of therapy with Dan and Shari was examining the profound ambivalence which may be experienced by victims of sexual coercion. Bograd (1992) stated that the victim's opposing feelings and wishes need to be clarified in treatment. The dynamic tension present in feelings of love and hate, security and panic, and in victims' wishes to continue or leave the relationship can produce considerable cognitive dissonance for victims. In this case example, the therapist attempted to help Shari escape her paralysis by facilitating her acknowledgment, acceptance, and integration of these affective polar opposites (Little, 1990).

The "up and down" nature of couple treatment for a problem as serious as sexual coercion must be acknowledged. During the course of therapy, Shari's and Dan's perceptions of the viability of the relationship and their individual convictions with regard to staying with one another underwent sweeping changes. Couple therapy worked to challenge Dan's and Shari's romanticism and to help them see beyond their relationship. By increasing clarity of the couple's issues, couple therapy may increase the likelihood that relationships will end. In this case, following several months of therapy, the two partners' commitments to a life together were no longer congruent. Although considerable progress was made with their communication, with Dan's anger/alcoholism, and with Shari's empowerment, they found themselves growing apart. Couple therapy ended with a tearful session in which they both acknowledged that their relationship was not working and that they needed to move on. 
Probably the most difficult issue to address in couple therapy when a woman has been victimized by her partner is sexual intimacy. In cases where the couple stays together we recommend that sex therapy approaches which fit the specific needs of the couple be used at the end of therapy. Usually a considerable amount of time and repeated demonstration of appropriate behavior by the male are necessary before the female is comfortable with and capable of exploring sexual issues in a therapeutic way. Both partners must be informed that it might be some time before the sexual area of their relationship is rewarding. In addition, the therapist should emphasize early in the couple sessions the ground rule that it is the woman's choice whether and how the couple will begin to relate sexually in the relationship again.

CONCLUSION

Premarital sexual coercion is a pervasive, destructive problem in our society. Although some may argue that couple therapy is inappropriate in cases of physical and sexual coercion, therapeutic work can be greatly enhanced by having access to relationship dynamics. Whether the couple stays together or not, as marriage and family therapists we believe that the complex issues involved in sexual coercion are more easily addressed in a combination of individual and couple sessions if both partners wish to stay together and safety issues are continually assessed. Since sexual coercion occurs in a relationship, it is our belief that revictimization and reperpetration can be reduced if some couple work is conducted. Still, there is a serious need to study the effectiveness of couple and individual treatment modalities to determine what is most helpful for clients.

\section{REFERENCES}

American Association for Marriage and Family Therapy. (1991). AAMFT code of ethics. Washington, MJ: Author. Abramson, L. Y., Seligman, M. E. P., \&Teasdale, J. D. (1978). Learned helplessness in humans: Critique and reformulation. Journal of Abnormal Psychology, 87, $49-73$.

Barrett, K. (1982, September). Date rape: A campus epidemic? Ms., pp. 48-51, 130.

Beavers, W. R. (1985). Successful marriage. New York: W. W. Norton.

Beck, A. T. (1988). Love is never enough. New York: Harper and Row.

Beeker, J. V., Skinner, L. J., Abel, M. D., \&Treacy, E. C. (1982). Incidence and types of sexual dysfunction in rape and incest victims. Journal of Sex and Marital Therapy, 8, 65-74.

Bograd, M. (1992, February). Domestic violence: Navigating therapy on stormy seas. Presentation at the annual conference of the Central New York Chapter of New York Association for Marriage and Family Therapy, Syracuse, NY.

Bowker, L. H. (1983). Marital rape: A distinct syndrome? Social Casework, 6, 347-352.

Brown, K. S., \&Ziefert, M. (1988). Crisis resolution, competence. and empowerment: A service model for women. Journal of Primary Prevention, 9(1-2), 92-103.

Burge, S. K. (1983). Rape: Individual and family reactions. In C. R. Figley \&H. I. McCubbin (Eds.), Stress and the family: Vol. 2. Coping with catastrophe (pp. 103-119). New York: Brunner/Mazel.

Burt, M. (1980). Cultural myths and supports for rape. Journal of Personality and Social Psychology, 38, 217-230.

Cate, R. M., Henton, J. M., Koval, J. E., Christopher, F. S., \&Lloyd, S. A. (1982). Premarital abuse: A social

psychological perspective. Journal of Family Issues, 3, 79-90.

Combrinck-Graham, L. (1991 ). Holding children accountable. Family Therapy Networker, 5(4), 48-52.

Davis, R. C., \&Friedman, L. N. (1985). The emotional aftermath of crime and violence. In C. R. Figley (Ed.), Trauma and its wake: The study and treatment of post-traumatic stress disorder (pp. 90-112). New York: Brunner/Mazel. Derogatis, L. R. (1975). Brief symptom inventory. Baltimore. MD: Clinical Psychometric Research.

Ellis, E. M., Atkeson, B. M., \&Calhoun, K. S. (1981). An assessment of long-term reaction to rape.

Journal of Abnormal Psychology, 90, 263-266.

Estrich, S. (1987). Real rape. Cambridge, MA: Harvard University Press.

Gibbs, N. (1995, June 3) When is it rape? Time, pp. 48-55.

Grauerholz, E., \&Koralewski, M. A. (1991). Sexual coercion. Lexington, MA: D. C. Heath.

Hanneke, C. R., \&Shields, N. A, (1985). Marital rape: Implications for the helping professions. Social Casework 6, 
451-458.

Harney, P. A., \&Muehlenhard, C. L. (1991). Rape. In E. Grauerholz \&M. Koralewski (Eds.), Sexual coercion (pp. 3-15). Lexington, MA: D. C. Heath.

Henton, J. M., Cate, R M., Koval, J. E., Lloyd, S. A., \&Christopher, F. S. (1983). Romance and violence in dating relationships. Journal of Family Issues, 4, 467-482.

Holman, T. B., Busby, D. M., \&Larson, J. H. (1989). PREParation for marriage. Provo. UT: Marriage Study Consortium, Brigham Young University.

Karpel, M. A. (1980). Family secrets: I. Conceptual and ethical issues in the relational context; II. Ethical and practical considerations in therapeutic management. Family Process, 19, 295-306.

Kanin, E. J. (1985). Date rapists: Differential sexual socialization and relative deprivation. Archives of Sexual Behavior, 14(3), 219-231,

Kelly, L. (1988). Surviving sexual violence. Minneapolis, MN: University of Minnesota Press.

Kieman, J. E., \&Taylor, V. L. (1990). Coercive sexual behavior among Mexican-American college students. Journal of Sex and Marital Therapy, 16(1), 44-50.

Kilpatrick, D. G., Veronen, L. J., \&Resick, P. A. (1979). The aftermath of rape: Recent empirical findings. American Journal of Orthopsychiatry, 49, 658-669.

Koss, M. P., \&Buckhart, B. R. (1989). A conceptual analysis of rape victimization: Long-term effects and implications for treatment. Psychology of Women Quarterly, 13, 27-40.

Koss, M. P., Dinero, T. E., Seibel, C. A., \&Cox, S. L. (1988). Stranger and acquaintance rape: Are there differences in the victim's experience? Psychology of Women Quarterly, 12, 1-24.

Koss, M. P., Gidycz, C. A., \&Wisniewski, N. (1987). The scope of rape: Incidence and prevalence of sexual aggression and victimization in a national sample of higher education students. Journal of Consulting and Clinical Psychology, 55, 162-170.

Koss, M. P., \&Oros, C. J. (1982). Sexual experiences survey: A research instrument investigating sexual aggression and victimization. Journal of Consulting and Clinical Psychology, 50, 455-457.

Leidig, M. (1981). Violence against women: A feminist psychological analysis. In S. Cox (Ed.), Female psychology (pp. 190-205). New York: St. Martin's.

Little, L. F. (1990). Gestalt therapy with females involved in intimate violence. In S. Stith, M. B. William, \&K. Rosen (Eds.), Violence hits home (pp. 47-65). New York: Springer.

Lloyd, S. A. (1991). The darkside of courtship: Violence and sexual exploitation. Family Relations, 40, 14-20.

Miller, B., \&Marshall, J. C. (1987). Coercive sex on the university campus. Journal of College Student Personnel, 28, 38-48.

Muehlenhard, C. L., \&Linton, M. (1987). Date rape and sexual aggression in dating situations: Incidence and risk factors. Journal of Counseling Psychology, 34, 186-196.

Napier, A. Y. (1987). Early stages in experiential marital therapy. Contemporary Family Therapy, 9(12), 23-41.

Olson, D. H., Fournier, D. G., \&Druckman, J. M. (1986). Prepare/Enrich counselor's manual. Minneapolis, MN:

Prepare-Enrich.

Rosenbaum, A., \&O'Leary, K. D. (1986). Treatment of marital violence. In N. Jacobson \&A. Gurman (Eds.), Clinical handbook of marital therapy (pp. 385-405). New York: Guilford.

Russell, D. E. H. (1984). Sexual exploitation: Rape, child sexual abuse, and workplace harassment. Beverly Hills, CA: Sage.

Shostrum, E. L. (1975). Caring relationship inventory: Manual. San Diego, CA: Educationald and Industrials Testing Service.

Snyder, D. (1985). Marital satisfaction inventory: Manual. Los Angeles, CA: Western Psychological Services.

Stahmann, R. F., \&Hiebert, W. J. (1987). Premarital counseling: The professional's handbook. Lexington, MA: Lexington Books.

White, P. N., \&Rollins, J. C. (1981). Rape: A family crisis. Family Relations, 30, 103-109. 
Willbach, D. (1989). Ethics and family therapy: The case management of family violence. Journal of Marital and Family Therapy, 5, 43-52.

Wolf, S. (1988). A model of sexual aggression/addiction. Journal of Social Work and Human Sexuality, 7 (1), 131148.

Kyle D. Killian, MA, is a doctoral student in the Marriage and Family Therapy Program, Department of Child and Family Studies, Syracuse University, Syracuse, NY 13244-1250.

Dean M. Busby, PhD, is an Assistant Professor in the Marriage and Family Therapy Program, Department of Child and Family Studies, Syracuse University, Syracuse, NY 13244-1250.

\section{DETAILS}

Subject:

Publication title:

Volume:

Issue:

Pages:

167

Number of pages:

Publication year: 1995

Publication date:

Apr 1995

Publisher:

Blackwell Publishing Ltd.

Place of publication:

Country of publication: United Kingdom, Hoboken

Publication subject:

ISSN:

Social Services And Welfare, Matrimony, Psychology, Sociology

$0194472 X$

e-ISSN:

17520606

CODEN:

JMFTDW

Source type:

Scholarly Journals

Language of publication: English

Document type: $\quad$ Feature
02329762 
Document URL: $\quad$ http://erl.lib.byu.edu/login/?url=https://www.proquest.com/scholarlyjournals/premarital-sexual-coercion-treatment-issues/docview/220941545/se2? accountid $=4488$

Copyright:

Copyright American Association for Marriage and Family Therapy Apr 1995

Last updated:

2015-07-25

Database:

Social Science Premium Collection,Research Library

\section{LINKS}

Linking Service

Database copyright (c) 2021 ProQuest LLC. All rights reserved.

Terms and Conditions Contact ProQuest 